AN ACCOUNT OF CASES OF CHRONIC LEAD POISONING, CAUSED BY DRINKING WATER KEPT IN A LEADEN CISTERN.

\author{
Bx JAMES ROBERTSON, M.D., F.R.C.S. \\ PHYSICTAN TO THE INFIRMARY, MITCHIN.
}

The school in which the following chronic poisoning by lead occurred, consists of about twenty girls, who have all the advantages deemed requisite by the poor-law authorities for the preservation of health. They were well clothed, kept scrupulously clean, had well constructed and efficiently managed dormitories, took regular and sufficient exercise, and their food was of good quality. Nothing appeared obnoxions to objection, notwithstanding which, for several months the children were not in good health. I was long unable to account for this, for the other inmates of the establishment appeared subject to like circumstances, yet were well. Most of the girls lost the colour of health from their faces; they became pale, puffy, and dark under the eyes; their appetites failed, but few, if any, were thinner than before; many had offensive breath; some were frequently ailing, some had tumid abdomen, some occasional diarrhœa, some obstinate constipation; their faces were smooth and clay coloured; their urine was unusually plentiful and limpid. The whole school had evidently declined in health, which was remarkable, for the system was one which had been tried for many years, and the children had been commonly healthy. I may mention, by the way, that the establishment was visited, some time since, by a medical practitioner in this neighbourhood, who spoke favourably of the health of the girls, and reported them as being in better health than the boys (for there is also a boy's school under the same roof); though persons of the establishment were not able to perceive any differonce, and considered both schools healthy; but I adduce this to show that their hygienic management was compatible with, not to say conducive to, good health.

However, for several months the general health declined, and for this no cause was apparent; their diet was varied and improved without benefit, and as for medicines, only purgatives appeared of use. When this state of affairs had existed for a while; one girl complained of head and belly ache; she was depressed; at times delirious; temples throbbing; pulse 130, feeble; skin hot and dry; no appetite nor thirst; respiration slow and sighing; epigastrium teuder; tongue red at the edge, a brown fur down the centre; bowels constipated; urine plentiful and limpid. Aperients produced plentiful, dark, and very offensive dejections. In a ferw days she was convalescent, but she remained long very debilitated, and had frequent faintings. Her face was dusky, I might say purple; her lungs acted well; there was no cough; $I$ could not find any unnatural sound in her chest by auscultation or percussion. This case was followed by several others, with some or all of these symptoms: head and belly ache; loss of appetite; sickness; rapid pulse; hot, dry skin; flushed, dusky countenance (two very dark); confined bowels; fæces pale urine plentiful, pale; tongue flabby, tr $:$ mulous, edges red, and indented, a brownish fur down the centre, speckled with enlarged red papillæ; gums generally pale and spongy. Several had fits, described as being hysterical; some had faintings; the majority had a relapse, and some even three times.

These illnesses caused me again very carefully to scrutinize every possible cause. The food and water were repeatedly examined, but the other inmates were known to take the same without any like effects being produced-at length, the lead cistern which contained water for the supply of the girls' washing-place attracted my attention, though I was assured they never used this water except for washing; however, I thought it probable, as the place was convenient for the playground, that they did drink this contrary to orders; and so it proved. They were in the constant habit of drinking this when they had no fresh well-water at hand. The water the cistern is supplied with is yielded by a well sunk in the chalk; it is very clear, sparkling, loaded with free carbonic acid, and chalk. On opening the cistern, I observed the surface covered with an iridescent film, broken at the edges, and at the part opposite the tap there was a clear, pear-shaped surface, the point at the tap indicating that a portion of this film had been drawn through the tap. The corner seams and bottom of the cistern were covered with a large quantity of white, heavy matter, which I afterwards ascertained, by analysis, to be chiefly carbonate of lead, with carbonate of lime. I next examined the filtered water, and found a very small quantity of lead in it, so small, that at the first analysis made at my request, it escaped detection; but I afterwards obtained ample evidence of its existence in several portions of the water which I analyzed.

I also carefully analyzed the evacuations of the children, but could not detect a trace of lead. The cistern was cleansed, care being taken that the water out of it should not be drunk; and the health of the school had three weeks afterwards much improved, and no fresh attacks had occurred.

Hitchin, 1850.

\section{REPORT OT A \\ CASE OF PARALYSIS OF THE RIGHT AND CHOREA OF THE LEFT SIDE.}

By C. J. B. ALDIS, M.D., F.R.C.P.

LECTURER ON MEDICINE AT THE HUNTERIAN SCHOOL.

A Box, aged five, residing at 31 , Rochester-street, Rochesterrow, Westminster, is now a patient at the Western Dis. pensary, on account of irregular motions of the left arm and leg, with frequent protrusion of the tongue, which he occasionally bites. There is also paralysis of the right arm, with slight flexure, and of the right leg, with loss of speech. The paralytic symptoms have existed for two years, and succeeded a fit supervening upon scarlet fever. He was quite insensible, and received attendance from the above dispensary. He recovered from the fit, which probably arose from effusion causing pressure upon, or injury in, the left hemisphere of the brain, which has occasioned the paralysis of the right side. The coincidence of paralysis and chorea in the manner just described is very rare, and the contrast between the loss of motion of one side and constant agitation of the other is very remarkable.

Chester-terrace, Chester-square, F $f$ b. 15, 1851.

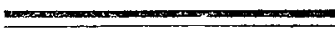 \\ A fitírar \\ OF THE PRACTICE OF \\ MEDICINE AND SURGERY HOSPITALS OF LONDON.}

Nulla est alia pro certo noscendi via, nisi quam plurimas et morborum, et dissectionum historias, tum aliorum proprias, collectas habere et inter se comparare.-Morgagnr. De Sed. et Caus. Morb., lib. 14. Procmium.

\section{ST. BARTHOLOMEW'S HOSPITAL.}

Efficacy of Cod-Liver Oil in arresting the Symptoms of Phthisis. (Under the care of Dr. Burnows.)

FEw remedies have of late been more extolled than cod-iver oil, and few, we may add, have caused so little disappointment as this valuable therapeutic agent. When it is considered how extensively it is used, it will be conceded that it must be very effectual, since it is keeping its ground in a very remarkable manner, though employed in thousands of instances. According to all appearance, cod-liver oil is not one of those ephemeral remedies destined to shed a doubtful light for a very short time, and be consigned to oblivion; but it is very likely to take rank in our pharmacopceia on the same footing as quinine, mercury, and iodine.

The services which the oil has rendered and will doubtless continue to afford in the destructive disease which it is intended to combat, have been very forcibly set forth by a physician who has used it largely. Dr. C. J. B. Williams states, in the London Journal of Medicine (Jan. 1849, p. 12):"The results above stated give to cod-liver oil, even as a tardative or palliative in phthisis, a rank far above any agent hitherto recommended, whether medical or regiminal. I have made extensive trials of several other medicines of reputed utility in this disease, and on a future occasion may lay before the profession the results of my experience, which prove some of these agents to be by no means inoperative and useless; and I still consider them to be often salutary aids in the treatment of this formidable malady, but their utility and harmlessness fall so short of those of cod-liver oil, that I regard them now chiefly as subsidiary means, and the more likely to be useful in proportion as they facilitate the exhibition or continuance of this superior agent." 